\title{
IAMJ
}

INTERNATIONAL

AYURVEDIC

MEDICAL JOURNAL

ISSN: 2320-5091

Impact Factor: 6.719

\section{AN AYURVEDIC REVIEW OF KARNANADA W.S.R. TINNITUS}

\section{$\underline{\text { Anubha Jain }}^{1}, \underline{\text { Mukesh Kumar Gupta }}{ }^{2}$}

Assistant Professor, Associate Professor and HOD, Department of Shalakya Tantra, Government Autonomous Dhanwantari Ayurved College, Ujjain, Madhya Pradesh, India

Corresponding Author: anubhajain05doctor@gmail.com

\section{https://doi.org/10.46607/iamj1709042021}

(Published online: April 2021)

Open Access

(C) International Ayurvedic Medical Journal, India 2021

Article Received:22/03/2021 - Peer Reviewed:30/03/2021 - Accepted for Publication:05/04/2021

Check for updates

\begin{abstract}
Karnanada considered as illness caused due to vitiated VataDosha in which a person hears different types of sound in absence of any relevant external stimulus. Now days, it can be considered as tinnitus, a disease with multifactorial etiology. It may be concerned with unhealthy condition of only ear, ear with head disease, only head disease or may be associated with general body condition. In tinnitus patient got ringing, buzzing or other type of sound in one or both ears which might be constant and inconstant often associated with hearing loss. In Ayurveda it is described as preliminary symptoms of hearing loss, which without treatment or with incomplete or improper treatment will progress towards hearing loss. In present scenario of electronic devices which produces electromagnetic waves (which are harmful to ear including whole body organs), number of such type of cases are increasing frequently worldwide. Causes of tinnitus according to modern medicine is unclear or having multiple etiologies therefore treatment guideline of tinnitus in modern practice is not definite hence prognosis of disease also remains uncertain. But in Ayurveda prognosis and line of treatment of Karnanada is mentioned and we can achieve good and satisfactory result.
\end{abstract}

Keywords: Karnanada, Tinnitus, Ayurveda 


\section{INTRODUCTION}

Elemental reason behind the setting up of any disease according to Ayurveda is AtiyogaHeenayoga and Mithyayoga of Karma, Kala and Artha (Indirya). ${ }^{1}$ Like asAtiyogaHeenayoga and Mithyayogaof Shabda might be the causal factor behind the genesis of Karnanada.

InKarnanada patient can hear different type of sound in ear which can be unilateral or bilateral and stable or transient type. This sound may vary in pitch, quality and loudness. It might be swishing, hissing, roaring, clicking, rustling type of noise. It is more irritating in silent environment as in night when the masking effect of ambient noise from environment is lost. It is a symptom not a disease and causes might be present in external, middle or inner ear in 8th nerve or inside the brain. Some systemic disorder like anemia hypo or hypertension, certain drugs which effect on inner ear or auditory pathway may also precipitate tinnitus. It can also result from prolonged exposure to excessive loud sound, which could be the possible reason of increasing cases of tinnitus in youngsters, as large number of young people uses mobile phones, headphone, ear phone etc. for longer duration which radiates electromagnetic wave and high level of electromagnetic field, which can be harmful to ear along with other body parts.

It is generally classified as either objective or subjective. Objective tinnitus in which sound produced by Para auditory structures which may be heard by patient and examiner both, often pulsatile in nature. In subjective tinnitus sound is only perceived by the patient. The great majority of the tinnitus sufferers have subjective tinnitus and generally when the word 'tinnitus' is used, it implies subjective tinnitus, which only is audible by the tinnitus patient. Instead of classifying tinnitus in 'subjective' or 'objective tinnitus', 'genuine tinnitus', could be used and replace the term 'subjective tinnitus'. Objective tinnitus (sometimes referred to as somatic tinnitus) in which is a sound sensations created by an acoustical source within the body, should rather be described by the condition causing this sensation and not be described as tinnitus. ${ }^{2}$ For tinnitus it's really tough to pin point the exact cause of disease, but it's generally agreed that it may come from any physical or mental change but not essentially related to the ear. Where possible cause discovered, and treated tinnitus get resolve but some time even the treatment of underlying disease cannot alleviate tinnitus.

Therefore, tinnitus can consequently be defined as "a sound sensation in the absence of an internal or external acoustical source or electrical stimulation", hence in this article we will discuss about subjective tinnitus. Cause: Causes of Karnanadawere not defined by any Acharya, even AcharyaShushruta did not describe common Karnaroga Nidanas but Acharya Yogratnakar has explained Samanya Karnaroga Nidanas. According to him Avashyaya (exposure to cold), Jalakrida (swimming, diving or any other means by which water can enter into ear canal) Karnakandu (improper aural scratching), Mithyayoga of Shastras(improper instrumentation) etc. and other similar causes which leads to vitiation of VataDosha. Further this DushitVata vitiate other Doshas, than these dust Doshas will reach to Karna (aural) Shiras and causes aural diseases. ${ }^{3}$ These above explained $\mathrm{Ni}$ danas can considered the causation factors of Karnanada. According to our Acharyas besides these factors any other condition which can causes vitiation of VataDosha may produces tinnitus. Such as, lack of adequate sleep, incessant talking, excess fasting, excess exercise, sudden shock/grief/fear, excess etc.

Other than Karnanada a similar disease namely Karnashweda also described by Acharya which has its own Nidanas such as, Shram (excessive work), Kshaya, Ruksha and Kashaya Bhojana Sewan and SheetSewan after Shirovirechana. ${ }^{4}$

Indeed, tinnitus is not a disease or illnessin itself but rather a symptom of any underlying disease which may lie inside or outside the ear.

Tinnitus may have its origin in external ear (impacted wax, foreign body, fungus), in middle ear (fluid, asom, csom, abnormally patent eustachian tube etc.) in internal ear (meniere's disease, otosclerosis), in $8^{\text {th }}$ nerve (tumour) or it may be associated with presbycusis, noise trauma, ototoxic drug intake ${ }^{5}$.In condition of 
presbycusis, the delicate and tiny sensory hair cells of cochlea get damaged and lost due to wear and tear phenomenon in aged people. This gradual change can cause hearing loss and makes tinnitus more noticeable due to absence of any sound from external surroundings which otherwise mask it. In case of noise trauma short term exposure to very loud sound can damage steriocilia which may lead to tinnitus or hearing loss or both. Ototoxic drugs also affect in similar way ${ }^{6,7}$

Causes those lies outside the ear i.e. nonotologic causes are, disease of CNS, anemia, hyper or hypotension, hypoglycemia etc. This above description is all about subjective tinnitus which can be only heard by the patient.

Objective tinnitus a condition in which sound can even be heard by patient and examiner (with the help of stethoscope) both. It is seen less frequently and can be found in neuromuscular lesion (palatomyclonus, stapedial muscle spasm) vascular lesion (glomustumor or carotid artery aneurysm which is synchronous with pulse). Tinnitus synchronous with respiration may be associated with abnormally patent Eustachian tube.

Symptom: In Karnanada an individual can hear different types of sound in absence of any relevant sound, due to vitiated VataDosha. According to Acharyas this sound generally resemble to musical sound of bherimrunagshankha (musical instrument used to be used in SamhitaKaal) appears after having Vata Prakopak Nidanas. An almost similar disease other than Karnanada is also described by our Acharyas i.e. Karnashweda in which patient can hear sound like Venughoshopamam i.e. flute like sound.

Tinnitus is an auditory sensation within the ear or head, i.e. perception of noise within those areas. Characteristic feature of Karnanada is that it is originated with in the patient. This may affect one or both ear or may be interrupted or continuous in nature. This sound appears in ear may vary in pitch (high or low), loudness (high or low) and in nature, it might be like hissing, roaring, swishing and clicking type of sound. It is more disturbing in quite environment because masking effect due to surrounding noise has lost.

Evaluation Of Tinnitus: Due to vast array of possible underlying diagnosis, careful evaluation of each patient who presents with tinnitus is warranted for assessment of tinnitus careful thorough history should be taken first and some question should be asked from the patient about the disease such as nature of sound (that may be buzzing, hissing, roaring, clicking, pulsatile in nature), pitch ( high or low), intensity (loud or soft), laterality (unilateral or bilateral), duration (constant or intermittent). Question about onset of disease and alleviating or aggravating factors should be asked. Any history about any infection, trauma, noise exposure, medication, hearing loss, vertigo, pain and family history about similar disease should be find out. General physical examination along with complete head \& neck examination with otoscopy should be performed.

Treatment: According to modern medical science there is no particular cure for tinnitus (as it is a symptom rather than the disease) for achievement of good result the patient should be investigated thoroughly to rule out any organic cause for tinnitus and if present, treatment should be directed towards the basic cause. If can't be able to find the cause than treatment should be starts with avoidance of dietary stimulants such as coffee, tea, cola, etc. with cessation of smoking. Vitamin B12 supplements, tranquilizer should be given (when patient having problem with sleep). Other forms of treatment include masking, hearing aids, biofeedback, and noise generators etc. If we failed to achieve good result than reassure the patient (because many times patient has to learn to live with it) and psychotherapy should be given., 8

As cases of tinnitus are increasing day by day specially in youngsters, we have to find proper treatment for this condition. According to our classics generally VataDosha lies behind the maximum aural disease and Karnanada is one among them. Hence Vata Shamaka treatment such as GhrutaPaana, Rasayana Sewan should be useful for it. ${ }^{10}$

Four disease namely Karnashula, Karnanada, Karnabadhirya and Karnasweda generally treated with same line of treatment. ${ }^{11}$ As tinnitus is a Vata disorder than Vata balancing herbs and therapies (Snehan, Sewdana, Nasya, Karnapoorana, Shiro and PadaAbhyang along 
with Medhya, Sedative or Balya Chikitsa) will be beneficial.

Snehan around the ear along with face with BalaTail, NarayanTail, DashmoolaTail followed by Swedana (hot fomentation) should be given. After that Karnapoorana with KsharTail, SharshapTailGruhadhumadilTail is given. If Kaphais predominant then Karnapoorana can be done after Vamana. Before Karnapoorana Nasya with AnuTail, BalaTail can also be given.

Abhyanga, Shiroabhyanga (head massage) and $\mathrm{Pa}$ dabhyanga (Foot massage with lukewarm BalaTail, KshirbalaTail, Sesame Tail, has a specific effect in calming the PranaVayu. At bedtime, warm oil should be applied to the soles of the feet and also to the scalp. This treatment rapidly normalizes the PranaVayu.

Karnapoorana (ear drops) to calm the Vata in the ears, few drops of warm oil is applied daily to each ear. The oil is allowed to remain in the first ear for ten minutes, then that ear is cleaned, and the same procedure is followed with the other ear, with the patient lying on the other side. Typically, this treatment should alleviate tinnitus, and most other symptoms of pranaVayu disturbance, within eight to ten days. BilwadiTail, ApamargksharTail, DashmoolTail, NarayanTail, VishnuTail, DipikaTail, HingwadiTail, NirgundiTail can be used for Karnpoorana. Kawala\&Gandusha may also have effect in strengthens the nerves of eyes and ears and also pacifies aggravated Vata. Acharya Chakraduttasaid that medicines used for VatajaShula is also helping in cure of Karnanada and Karnabadhirya. ${ }^{12}$

Along with above treatment Pratishyaya Shamak treatment with Medhya Aushadha (SaarivadiVati, BrahmiVati, Ashwagandha Churna, Shatavari Churna etc.) should be given for strengthening the nerve and achieving for better results.

Complication: Tinnitus (Karnanada) may leads to hearing loss (Karnabaadhirya) but it may not be necessary that all tinnitus cause hearing loss. ${ }^{13}$ People with high Vata imbalance or Vata body type are more prone to certain other disorders like hearing loss. So, these people prone to a condition called hyperacusis (certain high-frequency sounds can be very painful). It may lead to concentration problems, sleeping problems, irritation and annoyance. Hypersensitivity to sound or increased sensitivity in silence also observes. Chronicity of this problem causes despair, frustration and depression in many people.

\section{DISCUSSION}

Word tinnitus is derived from word tinnier which means "ringing" in Latin. It is a condition in which abnormal sound heard by the patient in absent of any external sources. It is a common problem with an extensive differential which generally associated with hearing loss and vertigo. 40 million peoples affected in the United States, $75 \%$ are not bothered by it, but 10 million severely affected. It is most common in 4070 -year-olds, with roughly equal prevalence in men and women. It includes buzzing, hissing, roaring, clicking, pulsatile nature sounds in single or both ears. It is more disturbing in quite surroundings, as it can't be masked by other noises. It is a condition rather than a disease itself and its causes may lie inside the ear (wax, foreign body, asom, otosclerosis) or in rest of the body (blood sugar level and blood pressure variation. There for prime treatment of tinnitus is to find the main cause of disease and then treat the same. Sometimes we fail to find the cause than patient has to learn to live with it but for some, an unbearable sound that drives them to contemplate suicide. Ayurvedic name for Tinnitus is Karnanada. According to Ayurveda, tinnitus in not a disease but a symptom of Prana Vayu disturbance. Prana Vayu is a subdosha of Vata which resides in the head and governs all higher cerebral functions. According to our classics in patient of Karnanada Vata reaches to Shabad Path and causes of production of vividh types of sound. The reasons which cause vitiation of Vata Dosha are also causing this disease

As it is a vataj disorder, it can be cured with vatashamaka treatment, which is similar to treatment of karnashula, karnabadhirya. For this we can give to patient Ghrutapana, Rasayansewan, naadisweda, karnapoorana, Shiro and Pada Abhyang along with Medhya, Sedative or Balya Chikitsa. If Karnanada is 
not treated properly than it may to leads hearing loss, concentration problem, sleep disturbance, depression etc. hence it has to treated carefully. Sometimes lifestyle changes such as avoidance of excessive uses of mobile phones, headphones, inadequate sleep can be beneficial.

\section{CONCLUSION}

The disease Karnanada which is described in classical Ayurvedic text can be considered as tinnitus, which is common problem with an extensive differential, but it is not a disease on its own. It has multifactorial etiology which may originating in the ears or around the head, brought on by factors including age, noise exposure, ototoxic medication, vascular problems, metabolic diseases, temporo-mandibular joint disorder or as a consequence of other disorder.

It is having a symptom of perception of sound in the absence of external stimuli or isn't caused by outside source which includes buzzing, hissing, roaring, clicking, pulsatile nature of sounds. It may be perceived as unilateral or bilateral.

As tinnitus has multiple etiologies, the first step of treatment according to modern practitioner, is to find the main cause of disease in the patient, sometimes even after cure of cause may not relieve the tinnitus, in such condition the patient has to learn to live with it. But according to Ayurveda this condition is appeared due to vitiation of VataDosha hence the treatment of approach is towards VataShaman, and we can achieve good results with this type of therapy such as Rasayana, MedhyaAushadha, Karnapoorana and with other Kriyakalpas.

\section{REFERENCES}

1. Upadhyaya Yadunandana, Ashtang Hrudayam, Vidyotiniy Hindi Commentary, Sutra Sthana 1/19, Chaukhambha Sanskrit Sansthan Varanasi. Reprint 2002:P10

2. Yvonne Chan, tinnitus: etiology, classification, characteristic and treatment, Discovery medicine, $10^{\text {th }}$ October- 2009

3. Vaidya Lakshmipati Sastri, Yogratnakar, Vidyotiniy Hindi Commentary, Pathyaapathyavidhi, Karnarogadhikar 1-2, Chaukhambha Sanskrit Series Office, Varanasi. Second edition: P-309
4. Shastri Ambikadutta, SushrutaSamhita, Ayurveda Tattva Sandipika Hindi commentary, Uttartantra 20/9, Chaukhambha Sanskrit Sansthan Varanasi. Reprint 2019:P- 116

5. Dhingra PL, Dhingra Shruti, Disease of ear nose and throat \& HEAD and neck surgery, $6^{\text {th }}$ edition (2014) Elsevier A division of Reed Elsevier India Private Limited. P-130

6. Maqbool Mohammad, Maqbool Suhail., Textbook of ear nose and throat disease, $11^{\text {th }}$ edition (2007), Jaypee brothers medical publishers LTD. P-113-114

7. Byung In Han, MD, Ho Won Lee, MD and Kyoung Sik Shin, tinnitus: characteristic causes, mechanism and treatment, journal of clinical neurology, feb-2009

8. Dhingra PL, DhingraShruti, Disease of ear nose and throat \&HEAD and neck surgery, $6^{\text {th }}$ edition (2014) Elsevier A division of Reed Elsevier India Private Limited. P-131

9. Maqbool Mohammad, Maqbool Suhail., Textbook of ear nose and throat disease, $11^{\text {th }}$ edition (2007), Jaypee brothers medical publishers LTD. P-114

10. Shastri Ambikadutta, SushrutaSamhita, Ayurveda Tattva Sandipika Hindi commentary, Uttartantra 21/3, Chaukhambha Sanskrit Sansthan Varanasi. Reprint 2019:P- 116

11. Shastri Ambikadutta, Sushruta Samhita, Ayurveda Tattva Sandipika Hindi commentary, Uttartantra 21/4, Chaukhambha Sanskrit Sansthan Varanasi. Reprint 2019:P- 127

12. Tripathi Indradev, Chakradutta, Vaidyaprabhahindi commentary, Karnarogachikitsa57/24, Chaukhambha Sanskrit Bhavan Varanasi. Reprint 2002:P- 339

13. Upadhyaya Yadunandana, Ashtang Hrudayam, Vidyotiniy Hindi Commentary, Uttar Sthana17/10, Chaukhambha Sanskrit Sansthan Varanasi. Reprint 2002:P509

\section{Source of Support: Nil \\ Conflict of Interest: None Declared}

How to cite this URL: AnubhaJain \& Mukesh Kumar Gupta: An Ayurvedic Review of Karnanada W.S.R. Tinnitus. International Ayurvedic Medical Journal \{online\} 2021 \{cited April, 2021\} Available from: http://www.iamj.in/posts/images/upload/794 798.pdf 